\title{
UPAYA PENINGKATAN HASIL BELAJAR MATEMATIKA SISWA MELALUI MODEL PEMBELAJARAN KOOPERATIF TIPE TUTOR SEBAYA DI SMP NEGERI 3 SATU ATAP BANGUN PURBA
}

\author{
Asmiah \\ Guru Matematika SMP Negeri 1 Bangun Purba \\ Surel : asmiah03@yahoo.co.id
}

\begin{abstract}
Abstrak
Penelitian ini bertujuan untuk melihat peningkatan hasil belajar siswa melalui model pembelajaran kooperatif tipe tutur sebaya. Awal KBM dilakukan tes hasil belajar (Pretes), dengan data rata-rata 26,1 hal tersebut menunjukkan bahwa ratarata siswa jarang membaca buku sebelum pembelajaran di sekolah. Kemudian dilanjutkan KBM, akhir KBM ke II dan KBM ke IV dilakukan tes hasil belajar formatif I dan formatif II dengan rata-rata hasil belajar masing-masing menunjukkan 60,7 dan 85,7. Data aktivitas siswa menurut pengamatan pengamat pada siklus I antara lain membaca/menulis (41\%), mengerjakan LKS (24\%), bertanya sesama teman ( $8 \%$ ), bertanya kepada guru (14\%), dan yang tidak relevan dengan KBM (13\%). Data aktivitas siswa menurut pengamatan pada siklus II antara lain membaca/menulis (24\%), mengerjakan LKS (50 \%), bertanya sesama teman (19\%), bertanya kepada guru (2\%), dan yang tidak relevan dengan KBM $(6 \%)$.
\end{abstract}

Kata Kunci: Model Kooperatif Tipe Tutor Sebaya, Hasil Belajar

\section{PENDAHULUAN}

Pada dasarnya banyak orang beranggapan bahwa matematika itu pelajaran yang sangat sulit untuk dipelajari. Hudojo (2001:40). Matematika adalah suatu alat untuk mengembangkan cara berfikir. Ini dikarenakan matematika sangat diperlukan pada kehidupan seharihari dan untuk menghadapi kemajuan IPTEK, sehingga perlu dibekalkan kepada peserta didik sejak dini. Sesuai dengan tuntutan perkembangan ilmu pengetahuan dan teknologi yang pesat sekarang ini mendorong pada peningkatan mutu pendidikan. Karena dengan

pendidikan dapat membantu
mengentaskan manusia dari
kebodohan, kemiskinan dan
keterbelakangan.
Keberhasilan pendidikan
dipengaruhi oleh pola yang
digunakan dalam mengajar, karena
pola yang digunakan dalam proses
belajar mengajar dapat berpangaruh
terhadap hasil belajar peserta didik.
Peningkatkan hasil belajar peserta
didik merupakan salah satu tujuan
pendidikan yang akan dicapai. Guru
dan peserta didik adalah faktor
dominan dalam kegiatan belajar
mengajar, maka untuk mencapai
tujuan pendidikan itu, peserta didik


melakukan belajar sedangkan guru melaksanakan pembelajaran.

Dalam kegiatan pembelajaran selalu dijumpai adanya peserta didik yang mengalami kesulitan dalam mencapai standar kompetensi, kompetensi dasar dan penguasaan materi pembelajaran yang telah ditentukan. Secara garis besar kesulitan dimaksud dapat berupa kurangnya pengetahuan, kesulitan memahami materi pembelajaran, maupun kesulitan dalam mengerjakan tugas-tugas latihan dan menyelesaikan soal-soal ulangan. Secara khusus, kesulitan yang dijumpai peserta didik dapat berupa tidak dikuasainya kompetensi dasar mata pelajaran tertentu, misalnya operasi bilangan dalam matematika.

Menghadapi peserta didik dengan berbagai pribadi dan beragam kesulitan

belajar, menuntut guru untuk memilih metode yang tepat untuk menyampaikan materi sesuai dengan perbedaan kemampuan otak peserta didik dan berusaha keras di dalam menjelaskan permasalahan dan menyajikan kata-kata dengan ungkapan yang jelas dan dapat dipahami sesuai dengan tingkatan para peserta didiknya.

Karenanya guru harus mengetahui model - model pembelajaran sebagai bagian dalam perencanaan mengajarnya, agar siswa dapat memahami yang berikan oleh gurunya secara seksama Salah satu model pembelajaran yang masih berlaku dan sangat banyak digunakan oleh guru adalah model pembelajaran konvensional. Memang, model pembelajaran kovensional ini tidak serta merta kita tinggal, dan guru mesti melakukan model konvensional pada setiap pertemuan, setidak-tidak pada awal proses pembelajaran dilakukan. Atau awal pertama kita memberikan kepada peserta didik sebelum kita menggunakan model pembelajaran yang akan kita gunakan.

Menurut Djamarah (diakses 20 Maret 2015) metode pembelajaran konvensional adalah metode pembelajaran tradisional atau disebut juga dengan metode ceramah, karena sejak dulu metode ini telah dipergunakan sebagai alat komunikasi lisan antara guru dengan peserta didik dalam proses belajar dan pembelajaran. Dalam pembelajaran sejarah metode konvensional ditandai dengan ceramah yang diiringi dengan penjelasan, serta pembagian tugas dan latihan.

Model ini sebenarnya sudah tidak layak lagi kita gunakan sepenuhnya dalam suatu proses pengajaran, dan perlu diubah, karena pembelajaran yang dilakukan kurang memberikan kesempatan seluasluasnya bagi peserta didik untuk aktif mengkonstruksi pengetahuannya. Tapi untuk mengubah model pembelajaran ini sangat susah bagi guru, karena guru harus memiliki kemampuan dan keterampilan menggunakan model pembelajaran Salah satu model pembelajaran yang dimungkinkan mampu mengantisipasi kelemahan model 
pembelajaran konvensional adalah dengan menggunakan model pembelajaran tutor sebaya dalam kelompok-kelompok kecil

Pemilihan model pembelajaran tutor sebaya sebagai strategi pembelajaran diharapkan dapat membantu peserta didik di dalam memahami materi pelajaran dan meningkatkan aktivitas belajar siswa. Dalam peningkatan aktivitas belajar melalui model pembelajaran tutor sebaya diharapkan peserta didik dapat melalukan pembelajaran dengan menggunakan bahasanya sendiri, sehingga peserta didik akan lebih mudah untuk menerima pelajaran dan juga tidak merasa takut untuk bertanya hal-hal yang kurang dimengerti.

Pembelajaran tutor sebaya dalam kelompok kecil merupakan model pembelajaran dimana peserta didik yang bertindak sebagai guru, tetapi sebelumnya peserta didik sudah berdiskusi tentang materi yang akan disampaikan dalam kelompokkelompok kecil yang heteroge Berdasarkan latar belakang maka yang menjadi indefikasi masalah dalam meningkatkan hasil belajar matematika yaitu (1) metode pembelajaran kurang bervariasi, (2) kurangnya minat belajar Matematika siswa, (3) siswa pasif dalam pembelajaran seperti tidak mau bertanya, tidak mau menjawab pertanyaan guru (4) guru tidak menggunakan media dalam mengajar sehingga siswa sulit memahami materi yang diajarkan. Dari indentifikasi masalah maka rumusan masalah adalah (1) Bagaimana hasil belajar siswa yang diajar dengan menggunakan model pembelajaran kooperatif tipe tutor sebaya? (2) Bagaimana aktivitas belajar siswa dengan diterapkannya model pembelajaran kooperatif tipe tutor sebaya selama KBM?

Adapun tujuan dari penelitan yaitu (1) untuk mengetahui bagaimana peningkatan hasil belajar siswa yang diajar dengan menggunakan model pembelajaran kooperatif tipe tutor sebaya, (2) Untuk mengetahui bagaimana aktivitas belajar siswa dengan diterapkannya model pembelajaran kooperatif tipe tutor sebaya.

\section{METODOLOGI PENELITIAN Lokasi dan Waktu Penelitian}

Penelitan ini termasuk dalam jenis Penelitian Tindakan Kelas. Penelitian Tindakan Kelas (PTK) yakni suatu pencermatan terhadap suatu kegiatan yang sengaja dimunculkan, dan terjadi di dalam sebuah kelas( Suharsimi Arikunto, dkk : 16: 2007). Pengambilan data untuk penelitian ini dilakukan di kelas IX-1 SMP Negeri 3 Satu Atap Bangun Purba dan pelaksanaannya dilakukan pada bulan Februari sampai dengan bulan Juli 2015. Penelitian ini merupakan penelitian tindakan kelas (Action Researh Classroom) karena penelitian ini bertujuan menganalisis atau memecahkan suatu masalah yang nyata dalam pendidikan. Hal-hal yang perlu di persiapkan sebelum 
melakukan penelitian adalah memilih model pembelajaran yang dinilai sesuai dengan materi yang akan disampaikan.

\section{SubjekPenelitian}

Populasi dalam penelitian ini adalah seluruh siswa kelas IX-1 SMP Negeri 3 Satu Atap Bangun Purba dan Subjek penelitian ini adalah siswa kelas IX-1 SMP Negeri 3 Satu Atap Bangun Purba Tahun Pelajaran 2014/2015, dengan jumlah siswa yang terikut dalam penelitian sebanyak 28 orang.

\section{Alat Pengumpul Data}

Alat pengumpul data dalam penelitian ini adalah tes berbentuk pilihan berganda, observasi, dan angket. Tes hasil belajar ini digunakan untuk mengetahui kemampuan siswa pada tingkat kognitif dan observasi untuk mengetahui aktivitas belajar siswa setelah menerapkan model pembelajaran kooperatif tipe tutor sebaya.

\section{Teknik Analisis Data}

Metode analisis data pada penelitian ini digunakan metode deskriptif dengan membandingkan hasil belajar siswa sebelum tindakan dengan hasil belajar siswa setelah tindakan.

Langkah-langkah pengolahan data sebagai berikut:

a. Merekapitulasi nilai pretes sebelum tindakan dan nilai tes akhir siklus I dan siklus II. b. Menghitung nilai rata-rata atau persentase hasil belajar siswa sebelum dilakukan tindakan dengan hasil belajar setelah dilakukan tindakan pada siklus I dan siklus II untuk mengetahui adanya peningkatan hasil belajar.

c. Penilaian

a) Data nilai hasil belajar (kognitif) diperoleh dengan menggunakan rumus:

Nilai Siswa $=\frac{\text { Jumlah jawaban benar }}{\text { Jumlah seluruh soal }} \times 100$ (Slameto,2001:189)

b) Nilai rata-rata siswa dicari dengan rumus sebagai berikut:

$$
\bar{X}=\frac{\sum X}{N}
$$

(Subino,1987:80)

Keterangan :

$\bar{X}=$ Nilai rata-rata

$\Sigma=$ Jumlah nilai $X$

$\mathrm{N}=$ Jumlah peserta tes

c) Untuk penilaian aktivitas digunakan rumus sebagai berikut:

\% Proporsi Aktivitas

$=\frac{\text { jumlah skor yang diperoleh }}{\text { jumlah skor ideal }} \times 100 \%$

(Majid, 2009:268)

d) Ketentuan persentase ketuntasan belajar kelas

Ketuntasan belajar kelas $=\frac{\sum S_{b}}{K} \times 100 \%$ 
$\Sigma \mathrm{Sb}=$ Jumlah siswa yang mendapat nilai $\geq 70$ (kognitif)

$\Sigma \mathrm{K}=$ Jumlah siswa dalam sampel Sebagai tolak ukur keberhasilan penelitian tindakan kelas ini dapat dilihat dari: hasil tes, jika hasil belajar siswa mencapai KKM secara individual dan $85 \%$ secara klasikal.

\section{Indikator Keberhasilan}

Yang menjadi indikator keberhasilan guru mengajar digunakan KKM mata pelajaran Matematik kelas IX-1 SMP Negeri 3 Satu Atap Bangun Purba dengan nilai 70 secara individual dan $85 \%$ secara klasikal.

\section{HASIL PENELITIAN DAN PEMBAHASAN \\ Deskripsi Hasil Penelitian}

Sebelum melaksanakan KBM

Siklus I, peneliti melaksanakan tes hasil belajar pada siswa untuk mengetahui awal siswa dalam materi Pangkat Tak Sebenarnya. Análisis data menunjukan hasil pretes siswa rata-rata adalah 26,1 hal ini menunjukan bahwa rata-rata siswa belum ada persiapan sebelum belajar di sekolah

\section{Data Siklus I}

\section{a. Perencanaan}

Pada tahap perencanaan maka peneliti membuat RPP, Lembar Kerja Siswa (LKS), soal tes hasil belajar, dan lembar observasi siswa. Guru juga membagi siswa menjadi 7 kelompok dengan menempatkan tutor (siswa yang berprestasi pada bidang studi Matematika) pada setiap kelompok.

\section{b. Pelaksanaan Tindakan}

Siklus I dilaksanakan dalam dua kali pertemuan. Proses pembelajaran dilakukan sesuai RPP yang telah disusun untuk siklus I. Pada pelaksanaan pembelajaran siklus I ini guru sebagai peneliti dibantu dua guru sejawat yang bertindak sebagai observer yang membantu peneliti mengamati aktivitas belajar siswa. Adapun yang menjadi observer peneliti yakni :Murniati Sembiring, S.Pd dan Kristin Henni Marini Saragih, S.Pd.

\section{c. Observasi}

\section{Data hasil belajar siswa}

Setelah

berakhirnya pelaksanaan siklus I diadakan tes hasil belajar kognitif yang selanjutnya disebut sebagai formatif I. Hasil belajar kognitif yang diperoleh pada siklus I selama dua pertemuan disajikan dalam Tabel 1. 
Tabel 1. Distribusi Hasil Formatif I

Formatif I

\begin{tabular}{|l|l|l|l|l|}
\hline Nilai & Frekuensi & $\begin{array}{l}\text { Tuntas } \\
\text { Individu }\end{array}$ & $\begin{array}{l}\text { Tuntas } \\
\text { kelas }\end{array}$ & $\begin{array}{c}\text { Rata- } \\
\text { rata }\end{array}$ \\
\hline 40 & 2 & - & - & \\
\hline 60 & 9 & - & - & \\
\hline 80 & 17 & 17 & $60,7 \%$ & \multirow{2}{*}{70,7} \\
\hline Jumlah & 28 & 17 & $60,7 \%$ & \\
\hline
\end{tabular}

Data aktivitas belajar siswa

Penilaian aktivitas

diperoleh dari lembar

observasi aktivitas dilakukan

pada saat siswa bekerja

dalam kelompok diskusi.

Pengamatan dilakukan oleh

dua pengamat yakni Murniati
Sembiring, S.Pd dan Kristin Henni Marini Saragih, S.Pd selama 20 menit kerja kelompok dalam setiap kegiatan belajar mengajar (KBM). Hasil observasi aktivitas siswa disajikan dalam Tabel 2.

Tabel 2 Skor Aktivitas Belajar Siswa Siklus I

\begin{tabular}{|l|l|l|c|}
\hline No & \multicolumn{1}{|c|}{ Aktivitas } & Skor & Persentase \\
\hline 1 & Menulis,membaca & 16 & $41 \%$ \\
\hline 2 & Mengerjakan LKS & 9,5 & $24 \%$ \\
\hline 3 & Bertanya pada teman & 3,25 & $8 \%$ \\
\hline 4 & Bertanya pada guru & 5,25 & $14 \%$ \\
\hline 5 & Yang tidak relevan & 5 & $13 \%$ \\
\hline \multicolumn{2}{|l|}{ Jumlah } & 39 & $100 \%$ \\
\hline
\end{tabular}

\section{d. Refleksi}

Merujuk pada Tabel 4.2 tersebut, nilai terendah formatif I adalah 40 dan tertinggi adalah 80. Merujuk pada KKM sebesar 65 maka hanya 17 dari 28 orang siswa mendapat nilai ketuntasan atau ketuntasan klasikal tercapai sebesar $60,7 \%$. Nilai ini berada di bawah kriteria ketuntasan klasikal sebesar 85 $\%$ sehingga dapat dikatakan KBM siklus I kurang berhasil memberi ketuntasan belajar dalam kelas. Nilai rata-rata kelas adalah 70,7. Rendahnya hasil belajar siswa tidak terlepas dari rendahnya aktivitas belajar siswa, dimana aktivitas belajar siswa yang paling dominan adalah 
menulis dan membaca (41\%), diikuti dengan aktivitas mengerjakan LKS (24\%), aktivitas bertanya pada teman (8\%) aktivitas bertanya pada guru (14\%), dan aktivitas yang tidak relevan dengan KBM (13\%).

Berdasarkan tes hasil belajar kognitif dan pengamatan siklus I menunjukkan bahwa masih terdapat beberapa permasalahan/kekurangan dalam pelaksanaan tindakan yang perlu diperbaiki secara lanjut. Beberapa kelemahan pada siklus I yang ditemukan dari faktor siswa yaitu:

a) Siswa masih belum terbiasa dengan model pembelajaran kooperatif tipe tutor sebaya, sehingga pelaksanaan terhambat oleh aktivitas yang tidak relevan dengan KBM. Siswa tampak bingung, siswa menggantungkan pekerjaan (LKS) pada teman satu kelompoknya sedangkan dia mengganggu temannya, atau diam dan menggambar di buku tulisnya.

b) Tutor tampak malu-malu dalam membimbing temannya. Tutor bekerja dengan dominan dan individual, akibatnya anggota kelompoknya bersifat pasif.

c) Tutor kurang terampil dalam membimbing teman satu kelompoknya, hal ini dikarenakan tutor sendiri belum menguasai materi ajar dengan baik.

d) Guru kurang dalam memotivasi siswa agar lebih aktif selama pembelajaran, akibatnya siswa kurang antusias selama pembelajaran.

\section{e. Tindakan Perbaikan}

Setelah melakukan refleksi, maka untuk menentukan tindakan perbaikan yang akan dilakukan peneliti melakukan diskusi dengan tutor dari UNIMED dan LPMP, teman sejawat dan pengamat peneliti, serta dengan pendamping peneliti dari UNIMED. Diskusi ditujukan untuk memperoleh tindakan perbaikan yang akan dilakukan pada siklus II. Hal ini dilakukan agar kesalahan pada siklus I tidak akan terulang dan diharapkan mampu meningkatkan aktivitas belajar siswa yang bermuara pada peningkatan prestasi belajar siswa. Berdasarkan diskusi tersebut maka diputuskan tindakan perbaikan sebagai berikut:

1. Bercermin dari kegagalan seorang tutor memperoleh KKM, maka guru akan membimbing setiap tutor di luar sekolah sebelum dilakukan pembelajaran di sekolah. Hal ini bertujuan agar masing-masing tutor menguasai materi ajar lebih dalam dan mampu membimbing temannya satu kelompok selama diskusi karena sudah dibekali oleh guru sebelumnya. 
2. Guru akan memberikan sanksi pada siswa yang tidak koperatif dan membuat keributan pada saat diskusi dan guru juga akan memberi sanksi bagi siswa yang tidak mengikuti aturan yang telah dibuat guru

3. Untuk lebih memotifasi siswa, guru akan membuat media berupa cerita yang sesuai dengan materi ajar yang akan ditempel di depan kelas agar siswa lebih mudah memahami tentang materi ajar.

4. Guru memotivasi siswa untuk lebih giat dan aktif selama diskusi dengan mengembalikan hasil diskusi mereka dan juga menginformasikan bahwa siswa yang tampak aktif akan memperoleh nilai lebih dari temannya yang kurang aktif.

\section{Data Hasil Siklus II}

\section{a. Perencanaan}

Materi yang akan dipelajari pada siklus II masih mengenai pangkat tak sebenarnya yang merupakan kelanjutan dari materi siklus I. Kelompok siswa juga masih akan sama, hanya saja pada siklus II setiap tutor masing-masing kelompok akan lebih dulu dibimbing dan diberi materi oleh guru di luar sekolah. Hal ini dilakukan agar masing-masing tutor dipastikan mengerti tentang bahan ajar, sehingga masing-masing tutor mampu membimbing bahkan mengajari teman-teman satu kelompoknya yang tidak mengerti. Selanjutnya peneliti merancang 2 RPP untuk KBM 3 dan KBM 4. Selain RPP, peneliti juga mempersiapkan lembar aktivitas siswa yang akan digunakan observer selama pengamatan, soal tes formatif II yang mewakili indikator yang dipelajari pada KBM 3 dan KBM 4 serta media pembelajaran.

\section{b. Pelaksanaan Tindakan}

KBM siklus II dilaksanakan dalam dua kali pertemuan berlangsung seperti dalam RPP dengan tindakan perbaikan pembelajaran seperti yang telah dirumuskan. KBM siklus II akan dilaksanakan pada tanggal 6 April dan 11 April 2015. Dalam siklus II juga dilakukan observasi aktivitas siswa oleh dua observer yakni Murniyati Sembiring, S.Pd dan Kristin Henni Marina Saragih, S.Pd. Berikut rekaman pembelajaran siklus II KBM 3 dan KBM 4.

\section{c. Observasi}

\section{Data hasil belajar siswa}

Diakhir siklus II diberikan tes hasil belajar sebagai formatif II dengan jumlah soal 5 item. Data formatif II disajikankan dalam Tabel 3. 
Tabel 3. Distribusi Hasil Formatif II

\begin{tabular}{|r|r|r|r|r|}
\hline \multicolumn{1}{|c|}{ Nilai } & Frekuensi & $\begin{array}{r}\text { Tuntas } \\
\text { Individu }\end{array}$ & Tuntas kelas & \multirow{2}{*}{ Rata-rata } \\
\cline { 1 - 3 } 60 & 2 & - & & \\
\cline { 1 - 3 } 80 & 16 & 16 & $57,14 \%$ & \multirow{2}{*}{85,7} \\
\hline 100 & 10 & 10 & $35,71 \%$ & \\
\hline Jumlah & 28 & 26 & $92,85 \%$ & \\
\hline
\end{tabular}

Merujuk pada Tabel 3 nilai terendah untuk formatif II adalah 60 dan tertinggi adalah 100 dengan 6 orang siswa mendapat nilai di bawah KKM atau ketuntasan klasikal adalah sebesar $87,5 \%$. Nilai ini berada di atas $85 \%$ sehingga dapat dikatakan KBM siklus II telah berhasil memberi ketuntasan belajar pada siswa dalam kelas. Nilai rata-rata kelas adalah 80,8 dan telah memenuhi KKM.

\section{Data aktivitas belajar siswa}

Aktivitas siswa pada siklus II mengalami peningkatan dibandingkan siklus I. Hasil pengamatan aktivitas belajar siswa pada siklus II disajikan pada tabel 4.4 .

Tabel 4. Skor Aktivitas Belajar Siswa Siklus II

\begin{tabular}{|c|l|c|c|}
\hline No & \multicolumn{1}{|c|}{ Aktivitas } & Skor & Persentase \\
\hline 1 & Menulis,membaca & 7,25 & $24 \%$ \\
\hline 2 & Mengerjakan LKS & 15,25 & $50 \%$ \\
\hline 3 & Bertanya pada teman & 5,75 & $19 \%$ \\
\hline 4 & Bertanya pada guru & 0,75 & $2 \%$ \\
\hline 5 & Yang tidak relevan & 1,75 & $6 \%$ \\
\hline \multicolumn{2}{|c|}{ Jumlah } & 30,75 & $100 \%$ \\
\hline
\end{tabular}

\section{d. Refeleksi dan Tindakan Perbaikan}

Berdasarkan data yang diperoleh selama siklus II, maka dapat diperoleh data sebagai berikut:

a) Terjadi peningkatan aktivitas belajar siswa dari siklus I ke siklus II. Hal ini dilihat dari meningkatnya aktivitas mengerjakan dari pada menulis, dan meningkatnya aktivitas bertanya pada teman dari pada bertanya pada guru.

b) Terjadi peningkatan prestasi belajar siswa. Pada siklus I rata-rata hasil belajar siswa yakni 70,7 menjadi 85,7 pada siklus II dan ketuntasan klasikal pada siklus I 60,41 \% dan pada siklus II menjadi $85,7 \%$. 
Dengan demikian hasil formatif II menyatakan bahwa pembelajaran siklus II telah berhasil meningkatkan hasil belajar siswa dan memberikan ketuntasan ratarata hasil belajar serta mampu memberikan ketuntasan belajar secara klasikal. Aktivitas belajar siswa pada siklus II juga mengalami peningkatan yang cukup signifikan. Berdasarkan dari seluruh data siklus II dapat disimpulkan bahwa siklus II berhasil meningkatkan aktivitas yang bermuara pada peningkatan hasil belajar siswa.

Sedangkan untuk perbaikan pembelajaran sudah tidak banyak yang harus direvisi. Hanya saja guru harus lebih terampil dalam membagi waktu dan menyiapkan media sebaik dan semanarik mungkin.

\section{Pembahasan}

a. Ketuntasan hasil belajar siswa

$$
\text { Melalui hasil }
$$

penelitian ini menunjukkan bahwa model pembelajaran kooperatif tipe tutor sebaya memiliki dampak positif dalam meningkatkan prestasi belajar siswa. Hal ini dapat dilihat dari semakin mantapnya pemahaman siswa terhadap materi yang disampaikan guru (ketuntasan belajar meningkat dari pretes, siklus I dan siklus II) yaitu masing-masing 0\%, 60,70\% dan $85,7 \%$. Pada siklus II ketuntasan belajar siswa secara klasikal telah tercapai.

b. Kemampuan Guru Dalam Mengelola Pembelajaran

Berdasarkan analisis data, diperoleh aktifitas siswa dalam proses belajar mengajar dengan menerapkan model pembelajaran kooperatif tipe tutor sebaya dalam setiap siklus mengalami peningkatan. Hal ini berdampak positif terhadap prestasi belajar siswa yaitu dapat ditunjukkan dengan meningkatnya nilai rata-rata siswa pada setiap siklus yang terus mengalami peningkatan.

c. Aktivitas Guru dan Siswa Dalam Pembelajaran

Berdasarkan analisis data, diperoleh aktifitas siswa dalam proses pembelajaran Matematika pada pokok bahasan Operasi Hitung Bilangan Bulat, dengan model pembelajaran kooperatif tipe tutor sebaya yang paling dominan adalah mengerjakan LKS dan aktivitas menulis dan membaca. Jadi dapat dikatakan bahawa aktifitas siswa dikategorikan aktif.

\begin{tabular}{|c|c|}
\hline Sedangkan & untuk \\
\hline $\begin{array}{l}\text { aktifitas guru } \\
\text { pembelaiaran }\end{array}$ & $\begin{array}{r}\text { selama } \\
\text { telah }\end{array}$ \\
\hline
\end{tabular}




\begin{abstract}
melaksanakan langkahlangkah kegiatan belajar mengajar dan menerapkan model pembelajaran kooperatif tipe tutor sebaya dengan baik. Hal ini terlihat dari aktivitas guru yang muncul, diantaranya aktivitas membimbing dan mengamati siswa dalam menemukan konsep, menjelaskan materi yang sulit, memberi umpan balik/ evaluasi/ tanya jawab dimana presentase untuk aktivitas di atas cukup besar.
\end{abstract}

\section{SIMPULAN DAN SARAN}

Setelah data-data tes hasil belajar, dan aktivitas belajar siswa terkumpul kemudian data tersebut dianalisis. Hasil analisis tersebut dapat disimpulkan sesuai dengan rumusan masalah, yaitu :

a. Hasil belajar siswa dengan menggunakan model pembelajaran tutor sebaya mengalami peningkatan.

Pada siklus I ketuntasan sebesar $60,7 \%$ dengan ratarata 70,7 dan belum tuntas secara klasikal dan pada siklus II sebesar 92,85\% dengan rata-rata 85,7 menunjukkan tuntas secara individu dan kelas. Dengan demikian model pembelajaran tutor sebaya dapat meningkatkan prestasi belajar Matematika siswa.

b. Data aktivitas siswa menurut pengamatan pengamat pada

\begin{abstract}
siklus I antara lain membaca/menulis (41 \%), mengerjakan LKS (24\%), bertanya sesama teman (8\%), bertanya kepada guru (14\%), dan yang tidak relevan dengan KBM (13\%). Data aktivitas siswa menurut pengamatan pada siklus II antara lain membaca/menulis (24\%), mengerjakan (50\%), bertanya sesama teman (19\%), bertanya kepada guru (2\%), dan yang tidak relevan dengan KBM (6\%).
\end{abstract}

\section{DAFTAR RUJUKAN}

Arikunto, Suharsimi. 2002. DasarDasar Evaluasi Pendidikan. Jakarta: Bumi Aksara.

Arikunto, Suharsimi. 2002. Prosedur Penelitian Suatu Pendekatan Praktek. Jakarta: Rineksa Cipta.

Degeng, I N. S. 1988. Ilmu Pengajaran: Taksonomi variabel. Jakarta : Depdikbud Dirjen Dikti P2LPTK.

Departemen Pendidikan dan Kebudayaan, 1994. Petunjuk Pelaksanaan Proses Belajar Mengajar. Jakarta: Balai Pustaka.

Djamarah, Syaiful Bahri. 2002. Strategi Belajar Mengajar. Jakarta: Rineksa Cipta.

Ginting, Dra. Julistina.2012.Tutor Sebaya Dalam Meningkatkan Aktivitas Belajar Siswa SMK Negeri 1 Kabanjahe T.P 2011/2012. Kabanjahe. 
Hamalik, Oemar. 1994. Metode Pendidikan. Bandung: Citra AdityaBakti.

Joyce, Wheil, dan Calhoun. (2010). Model's of Teaching (ModelModel Pengajaran. Yogyakarta: Pustaka Pelajar Kemmis, S. dan Mc. Taggart, R. 1988.The Action Research Planner.Victoria Dearcin University Press.

Margono. 1997. Metodologi Penelitian Pendidikan. Jakarta: Rineksa Cipta.

Nur, Moh. 2001. Pemotivasian Siswa untuk Belajar. Surabaya: University Press. Universitas Negeri Surabaya.

Slameto. (2003). Belajar dan Faktor-Faktor yang Mempengaruhinya. Jakarta: Rineka Cipta.

Syah, Muhibbin. 2006. Psikologi Pendidikan dengan Pendekatan Baru, Bandung : PT Rasda karya.

TuhusertaSawali. 2007. Diskusi Kelompok Terbimbing Model Tutor Sebaya. Alamat Web :http://sawali.infoltutor sebayalDiskusi Kelompok Terbimbing Model Tutor Sebaya _ Catatan Sawali Tuhusetya.htm. 
